\title{
MTHFD2 wt Allele
}

National Cancer Institute

\section{Source}

National Cancer Institute. MTHFD2 wt Allele. NCI Thesaurus. Code C104944.

Human MTHFD2 wild-type allele is located in the vicinity of 2p13.1 and is approximately

$19 \mathrm{~kb}$ in length. This allele, which encodes bifunctional methylenetetrahydrofolate

dehydrogenase/cyclohydrolase, mitochondrial protein, plays a role in folic acid

metabolism. 